\title{
THE URGENCY OF DONATED LAND CERTIFICATION IN SAMPANG REGENCY OF MADURA
}

\author{
Moh. Wardi \\ (Tarbiyah Faculty STAI Nazhatut Thullab Sampang, Jl. Diponegoro No. 11 \\ Sampang Regency of Madura, Email:wardi_84@yahoo.co.id)
}

\begin{abstract}
:
People donated their property such as lands or buildings because of charity of their selfand familyand for the sake of hereafter investment. However, there some obstacles faced to certify the given donated land, particularly in terms of administration and finance. The purpose of this research is to identify and explain the urgency, problems, and alternative solutions concerning the donated land certification in Sampang subdistrict. The research method used in this research was qualitative research with a focus on phenomenological research type. The data was obtained through interview and observation. Then, the data was analyzed by using data reduction, data display or data presentation, and data conclusion. The informants in this research were people in Sampang subdistrict consisting of 20 people. The research findings showed: The first, people donated their property because of charity of their self and family. Landsor buildings were registered to have a donatedland certificate in order to avoid an accusation from the heir of the land or building being donated in the future. The second, the famous phenomenon and problem in donation (waqf) were that the process of donated land submission conducted by a wâqif [a person who donated the land or the building] to a nâdzir [a committee or person who who received the donation] without the approval of wâqif heirs. In addition, the service was different in terms of administration and the amount of money should be paid from a donated and non-donated land certification in National Land Affairs Agency (BPN). The third, the alternative solution which is provided was thatthe submission of donated property is not enough to doonly through verbal agreement, but this wassuggested to that wâqif and nâdzir had to sign an official agreement or memorandum of understanding $(\mathrm{MoU})$. When the required documents of certifying the donated property was not proceeded yet by or they lasted very long in in PPAIW and BPN, the relevant action that should be taken wasto clarify what the prime problem are to the PPAIW and BPN officer.
\end{abstract}

al-1hkâm Vol.11 No.1 Juni 2016

DOI: http://dx.doi.org/10.19105/al-ihkam.v11i1.750 
The Urgency of Donated Land

\title{
Key Words:
}

Certification, Donated Land, Wâqif, Nâdzir

\begin{abstract}
Abstrak:
Masyarakat mewakafkan harta bendanya berupa tanah dan atau bangunannya karena semata-mata amal jariyah diri dan keluarga untuk investasi akhirat. Namun, dalam rangkaian prosesnya, ia menuai problem yang menghambat proses sertifikasi tanah wakaf, di antaranya adalah masalah administrasi dan pembiayaan. Tujuan penelitian ini adalah untuk mengetahui dan menjelaskan problem, dan solusi alternatif tentang sertifikasi tanah wakaf di Kecamatan Sampang. Metode yang digunakan dalam penelitian ini adalah kualitatif dengan jenis penelitian fenomenologis. Data diperoleh dari hasil wawancara dan observasi. Selanjutnya, analisis data dilakukan dengan reduksi data, display atau penyajian data, dan tahap kesimpulan. Informan dalam penelitian masyarakat Kecamatan Sampang yang terdiri atas 20 wâqif. Hasil penelitian menunjukan: Pertama, masyarakat mewakafkan harta bendanya karena sematamata amal jariyah diri dan keluarga. Tanah/bangunan didaftarkan sertifikat tanah wakaf supaya tidak ada gugatan di kemudian hari dari ahli waris. Kedua, fenomena dan persoalan yang lazim dalam perwakafan, bahwa pada saat penyerahan tanah wakaf oleh wâqif kepada nâdzir tanpa persetujuan dari calon ahli waris wâqif. Selain itu, ada versi yang berbeda di masyarakat tentang pelayanan, frekuensi administrasi, dan nominal biaya antara tanah wakaf dan non wakaf di BPN. Ketiga, solusi alternatifnya, bahwa penyerahan harta wakafnya tidak cukup melalui lisan/perkataan, namun dengan perjanjian/MoU. Langkah-langkah yang paling relevan ketika berkas mengendap/lama di PPAIW dan BPN yaitu menindak lanjuti akar persoalannya ke PPAIW dan BPN.
\end{abstract}

\author{
Kata-kata Kunci: \\ Sertifikasi, Tanah Wakaf, Wâqif, Nâdzir
}

\section{Introduction}

A land which Isa gift from the God almighty has a long lasting relationship with human in the world. All human activities in the world are almost and always associatedwith a land. For example, humanwas created from the land and willreturn back to land. Most 
people say that the land is the first and last place for human in the universe. With the increase of human populationwhich isfollowed by the development of human activities, the need of the land also increases. The land area is static and fixed and getting restricted. Therefore, to fulfill the demand of the land, this is often found the annexation, plunder and competition, quarrels and even a physical conflict occurs in order to get the intended land which often ends in bloodshed. ${ }^{1}$

The issue of the land is currently getting developed and become a cross-sectorial and multi dimensional problem compared to what happened in the past time in which the land issue was only agriculture issue and agrarian affair. Now a days, the issue of the land turns into a social dimension, cultural, economic, defense and safety issue within society.The land plays very important role in social life, either as a residence, business activities, a place of education, worship or others. The function of the land for activities such as mentioned above can be obtained through the purchase, exchange, lease, grant, inheritance and by donation.

Basically, the donation is prescribed in Islam to have two dimensions, these are a religious dimension and a social dimension. Religious dimension means that the donation is an advice in Islam that needs to be practiced in social life. Thus, those who give donation (wâqif/giving some lands for the investment of hereafter) will get reward from Allah SWT. In terms of social dimension, the donation consists of values of tolerance, friendly society, generosity, communicativeness, kindness, and has a high solidarity of others. The donated land is one of the social worships in Islam that relates to agriculture, the earthand water. The earth which is a gift from the God Almighty has a social function which will bring benefits for public interest. The issue of donated land and donation as well as their existence are recognized and protected by the state. ${ }^{2}$ Therefore, they are not only stated in Islamic law, but also stated by National Land Agency Law (BPN).

1Phenomenon of land dispute which ends with bloodshed (carok) happened in Bujur Tengah Village, Pamekasan Regency of Madura on August 2006.

${ }^{2}$ Law No. 5 of 1960 about the Basic Regulation of Agrarian article 1 paragraph (2) and article 6 . 
The enthusiasm of people toward the implementation of donation (waqf) has attracted government attention to regulate management of donation with the purpose of building the social and economic solidarity. The discussion of donation in the legislation has been carried out in Indonesia since the colonial era up to the present time. In its development, the donation of land has been officially endorsed and protected by law in Indonesia. This can be traced in the renewal of Agrarian Law as stated in article 49 paragraph 3 of Law No. 5 of 1960 about the Basic Regulation of Agrarian which states: "donated lands are protected and regulated by the government". ${ }^{3}$

From fourteen (14) sub districts in Sampang regency, in general each sub district has the same problems, namely: the first, the donated lands have not gotten the donation certificate yet (AIW) from PPAIW KUA of sub districts. The second, the donated lands do not get official legal statement [Donated Land Certificate] from the National Land Affairs Agency (BPN). Based on the data from the Ministry of Religious Affairs, Sampang, this is known that the amount of donated land in Sampang until 2014 is 134 locations. The donated land which has donationdeclaration certification and has been registered in BPN (National Land Affairs Agency) is 20 locations (15\%), while those which are not yet registered are 114 locations (80\%), and the otherswhich are still in process of registration are $5 \% .4$

The purpose of this research is to describe and explain: the first is the contribution of donated land certification, the second is the donated land certification problems in subdistrict of Sampang and the third is the alternative solutions of donated land certification in subdistrict of Sampang. The significance of this research is to be theoretical and practical benefits in the preservation of donatedland certification. The first, it can protect donated land in the subdistrict of Sampang. The second, it maintains and secures assets of donatedland in order to avoid quarrels in the next time because it has already legal certificate. The third, the establishment of public awareness is very important concerning the importance of donations, donation

${ }^{3} Z$ ulfirman, Wakaf dalam Perundang-Undangan di Indonesia, Paper of International Seminar on Waqf as Private Legal Body in Medan on January 6-7, 2003, 5.

4Publication of Directorate of Benefaction Empowerment, Ministry of Religious Affairs, March 14, 2014. 
declaration certification (AIW) and donated land certification. The fourth, it can optimize and maximize the role and function of donation declaration certification office (PPAIW) at the office of religious affairs (KUA) within subdistrict of Sampang and the National Land Affairs Agency (BPN) of Sampang.

\section{Research Method}

This research used social definition paradigm, which emphasized on social reality that was subjective definition and assessment. The basic principle of social paradigm is: The first, individual addresses something or what is happening in their environment based on the meaning of the object. The second, the meaning is given based on social interaction established with other individuals. The third, the meaning is understood and modified by individuals through interpretation related to things encountered ${ }^{5}$ with the phenomenological theory.

In this research, I used a qualitative approach that aimed at understanding the phenomenon about what was experienced by research subject, such as behaviors, perceptions, motivations, actions holistically. Those were described in the form of words and language within a specific context that is naturally applies a variety of natural methods. ${ }^{6}$ Based on its goal, this kind of research can be categorized as developmental research ${ }^{7}$ because it intends to conduct a descriptive study on donated land certification in subdistrict of Sampang.

Then, based on its nature, this research is categorized as case study research. The following are characteristics of case study research: The first, the target of research can be human research, events, and background documents. The second, the goals are explored in depth as a totality matches the background or context respectively. ${ }^{8}$

\footnotetext{
5Imam Suprayogo and Tobroni, Metodologi Penelitian Sosial Agama, (Bandung: Remaja Rosdakarya, 2001), 100.

6Lexy J. Moleong, Metodologi Penelitian Kualitatif, (Bandung: PT Remaja RosdaKarya, 2006), 6 .

7Suharsimi Arikunto, Prosedur Penelitian Suatu Pendekatan Praktis, (Jakarta: Rineka Cipta, 2002), 6.

8Imron Arifin, Penelitian Kualitatif dalam Ilmu-Ilmu Sosial dan Keagamaan, (Malang: Kalimasahada Press, 1996), 57.
} 
In this research, the type of data is statements conveyed by subjects of research in accordance with a set of questions put forward in this research. A documentation functions as reinforcement of data obtained by the statement of the research subjects.

\begin{tabular}{|c|l|l|}
\hline NO & \multicolumn{1}{|c|}{ NAMES } & \multicolumn{1}{|c|}{ ADDRESS/DELEGATION } \\
\hline 1 & Suroso & Jl. Kramat No. 99 Sampang \\
\hline 2 & Siti Aminah & Jl. H. Abdullah Sampang \\
\hline 3 & Amsadin & Desa Baruh Sampang \\
\hline 4 & Hosnan & Desa Baruh Sampang \\
\hline 5 & Siti Rodiyah & Desa Taman Sareh Sampang \\
\hline 6 & Moh Said & Jl. Kramat Gg. II Sampang \\
\hline 7 & Ismail & Pulau Mandangin Sampang \\
\hline 8 & H. Zainuddin & Jl. Rajawali Gg. I Sampang \\
\hline 9 & Moh. Ghufron & Yayasan Tanwirul Islam II Smpg \\
\hline 10 & H. Suudi & Jl. Barisan Indah Sampang \\
\hline 11 & Moh Tahsin & Jl. H. Agus Salim/ TPA Sampang \\
\hline 12 & Moh Halimi & Jl. H. Agus Salim Sampang \\
\hline 13 & Moh Masyhudi & Jl. H. Agus Salim Sampang \\
\hline 14 & Imam Syafi'ih & Desa Gunung Maddah Sampang \\
\hline 15 & Mukit & Desa Gunung Maddah Sampang \\
\hline 16 & Badrus Sholeh & Desa Gunung Maddah Sampang \\
\hline 17 & H. Hadrawi & Desa Banyumas Sampang \\
\hline 18 & Sohibul Anwar & Desa Karang Dalem Sampang \\
\hline 19 & KH. Fauzan & Desa Gunung Maddah Sampang \\
\hline 20 & Hilal & SDI Nurul Jadid Sampang \\
\hline
\end{tabular}


This research applied some steps in analyzing the data during data collection, namely: the first is checking the gathered data. The data which were derived from the transcript of the interview, observation and documentation were checked or examined with a purpose to determine the level of completeness of data or information required. The second is organizing the selected data. After checking the data, the next step is to organize the chosen data. Organizing data was done by sorting out or classifying the data according to research focus. The researcher classified the selected into different sheets to easily analyze the selected data. In this qualitative research, the data analysis was conducted either simultaneously with data collection or after the data were collected. The process of data collection in qualitative research must be followed by draft writing, editing, classifying, reducing and presenting the data. ${ }^{9}$

\section{The Research Findings and Discussion}

Etimologically the word "wakf" (donation) is derived from Arabic language "waqafa yaqifu waqfan" which means to stop, to show, to pay attention, to resist and to remain standing. While the word "alwaqf" is "masdar"in Arabic term "waqfu al-syay" meaning to restrain anything. ${ }^{10}$ According to syarîah terminology, donation means to resist the property that may bring benefits without spending or destroying the object and it is usually used for good deeds. ${ }^{11}$

Some Islamic scholars on law have different opinion in defining the term of donation. They define and interpret donation in accordance to the school of thought they follow. Al-Nawâwî, for example, as followers of al-Syâfi'î school argues that donation is to resist assets or property and distribute its benefits by maintaining the cost of goods and immortality that come from the donors for the purpose to do worship to Allah Almighty. ${ }^{12}$

\footnotetext{
9Ibid., 84

${ }^{10}$ Chairuman Pasaribu Suhrawardi K. Lubis, Hukum Perjanjian dalam Islam, (Jakarta: Sinar Grafika, 1996), 104.

${ }^{11}$ H. Adijani Al-Alabij, Perwakafan Tanah di Indonesia: Dalam Teori dan Praktek, (Jakarta: PT. Raja Grafindo Persada, 2002), 25.

${ }^{12}$ Abdul Ghofur Anshori, Hukum dan Praktik Perwakafan di Indonesia, (Yogyakarta: Pilar Media, 2005), 8.
} 
The implementation of donation practices that was recommended by prophet Muhammad was exemplified by 'Umar bin Khaththâb and this was followed by several other companions of the prophet Muhammad by emphasizing the importance of resisting the existence of the donation objects. The intended meaning of what the prophet Muhammad has said is that the core of donation does not merely focus on the maintenance of donation objects, but rather on the value of these objects for the benefit of the public policy interests. ${ }^{13}$

Certification procedures of unmoving donated property, in accordance with the article 16 paragraph (2) immovable objects that can be donated, are as follows: 1) The right to the land based on the law is applicable either it has been registered or not; 2) the buildings or parts of the buildings which are built on the land; 3) the plant and other objects that are related to the land; 4) the ownership of the apartment unit which is in accordance with applicable law and regulation; 5) another immovable objects are in accordance with the syarî'ah and legislation.

The procedure of making donation declaration certification (AIW) and registration is as follows: Thefollowing requirements should be fulfilled to managea donation declaration certification: 1) a certificate showing the right on theland; 2) a certificate which is issued by the head of avillage and acknowledged by sub-district major clarifies that the land is not in quarrel; 3) SKPT which is issued by sub-district land office; 4) there must be a candidate of wâqif who wishesto donate their own land; 5) there must be anadzir, a person who will receive the donation [can be an individual and legal agency endorsed by the governmentof Indonesia].

The process of managing the donation declaration certification is that the candidate of wâqif must come to the office of donation declaration certification (PPAIW) bringging a certificate showing the right of theland and other documents. The officer will check the following requirements: 1) Investigating the candidate of wâqif and land that will be donated. 2) Investigating nâdzir by using W.5 / W.5a. 3) Investigating the witnesses of declaration of donation. 4) Watching the implementation of declaration of donation; 5) the candidate of

13 Nasarudin Umar, Paradigma Baru Wakaf di Indonesia, (Jakarta: Direktorat Jenderal Bimbingan Masyarakat Islam, 2007), 57. 
wâqif expresses the donation orally, clearly and firmly to nâdzir in front of PPAIW and witnesses and this will be written using W.1 form; 6) Investigating identity of wâqif (identity card, family card, marriage certificate, passport, etc.); 7) Investigating identity of nâdzir. 8) The candidate of waqif who does not come at the office of PPAIW can authorize to a person with the recognition of a notary public orministry of religious affair and then the authorization is read by nâdzir in front of PPAIW and witnesses; 9) PPAIW makes three pieces of AIW 3according to the form of W.2 and then they are copied four pieces each according to the form of W.2a.

After recording the certificate of endowment pledge, PPAIW on behalf nâdzir obliges to apply for registration at the land office district and he has to submit: 1) A certificate of the land; 2) A certificateof the endowmentpledge; 3 ) the ratification of KUA about nâdzir; 4) Head of the district office on land affairs; 5) Place the word "wakaf" in capital letters on the back of the number of land rights in the book of land and the certificate. 6) Place the words "donated for ... based on AIW PPAIW" 7) Put the word "nâdzir", the name of nâdzir along with his position, in the book of land and the certificate.

Sampang regency has 14 sub districts; the following are data of donation land based on the publications of Directorate of donation of the Ministry of Religious Affairs, on March 14, 2014:

\begin{tabular}{|c|c|c|c|c|c|c|c|}
\hline \multicolumn{8}{|c|}{ The Amount ofDonatedLand in Sampang Regency East Java } \\
\hline \multirow[t]{2}{*}{ No } & \multirow{2}{*}{$\begin{array}{c}\text { Religious Affair } \\
\text { Office (KUA) }\end{array}$} & \multirow[t]{2}{*}{ Total } & \multirow{2}{*}{$\begin{array}{l}\text { Wide } \\
{[\mathrm{Ha}]}\end{array}$} & \multicolumn{2}{|c|}{ Certified } & \multicolumn{2}{|c|}{ Non- Certified } \\
\hline & & & & Total & $\begin{array}{l}\text { Wide } \\
\text { [Ha] }\end{array}$ & Jml & $\begin{array}{l}\text { Luas } \\
{[\mathrm{Ha}]}\end{array}$ \\
\hline 1 & Sampang & 4 & 0,16 & 0 & 0,00 & 4 & 0,16 \\
\hline 2 & Camplong & 23 & 0,84 & 0 & 0,00 & 23 & 0,84 \\
\hline 3 & Omben & 35 & 15,05 & 1 & 1,01 & 34 & 14,04 \\
\hline 4 & Torjun & 37 & 3,46 & 18 & 1,06 & 19 & 2,41 \\
\hline 5 & Jrengik & 0 & 0,00 & 0 & 0,00 & 0 & 0,00 \\
\hline 6 & Sreseh & 19 & 17,58 & 0 & 0,00 & 19 & 17,58 \\
\hline 7 & Kedungdung & 0 & 0,00 & 0 & 0,00 & 0 & 0,00 \\
\hline 8 & Tambelangan & 10 & 1,63 & 0 & 0,00 & 10 & 1,63 \\
\hline 9 & Robatal & 6 & 0,22 & 1 & 0,03 & 5 & 0,19 \\
\hline 10 & Ketapang & 0 & 0,00 & 0 & 0,00 & 0 & 0,00 \\
\hline
\end{tabular}




\begin{tabular}{|c|l|c|c|c|c|c|c|}
\hline 11 & Banyuates & 0 & 0,00 & 0 & 0,00 & 0 & 0,00 \\
\hline 12 & Sokobanah & 0 & 0,00 & 0 & 0,00 & 0 & 0,00 \\
\hline 13 & Pangarengan & 0 & 0,00 & 0 & 0,00 & 0 & 0,00 \\
\hline 14 & Karang Penang & 0 & 0,00 & 0 & 0,00 & 0 & 0,00 \\
\hline
\end{tabular}

The contribution of land certification in Islamic perspective, as mandated in the opening of Constitution of the Republic of Indonesia in 1945, is to promote public welfare. To achieve the mentioned goal, we need to explore and develop the potential within religious institutions that have economic benefits. One of the strategic actions to promote general welfare is that theneed to increase the role of donation as a religious institution which does not only aim at providing various means of worship and social activities but also having economic potential, such as to promote public welfare that need to be developed and utilized in accordance with Islamic principles.

The implementation of donation practices that was recommended by prophet Muhammad was exemplified by 'Umar bin Khaththâb and this was followed by several other companions of the prophet Muhammad by emphasizing the importance of resisting the existence of the donation objects. The intended meaning of what the prophet Muhammad has said is that the core of donation does not merely focus on the maintenance of donation objects, but rather on the value of these objects for the benefit of the public policy interests.

Allah SWT states in Q.S al-Baqarah 2: 261-262:

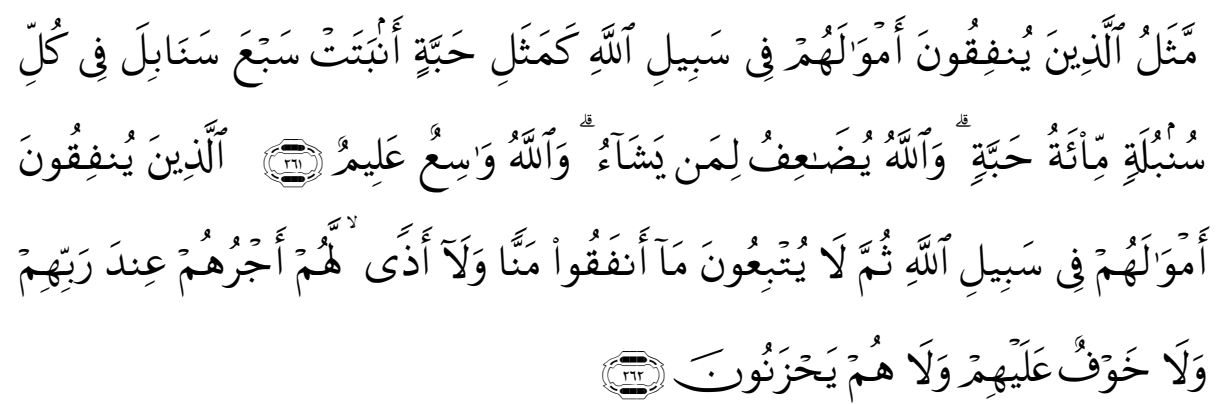

Parable (income incurred by) those who spend their wealth in the way of Allah is like a seed that grows seven ears, in every ear a hundred grains. God magnifies (reward) for whom he will. And Allah is the area (his gift) again Knowledgeable. Those who spend their wealth in Allah's way, then they do not accompany what feed it with 
mention of its grant and to not hurt (feelings of the recipient), their reward is with their Lord. No fear come upon them and not (also) they grieve.

And in Q.S Alî 'Imrân 3: 92

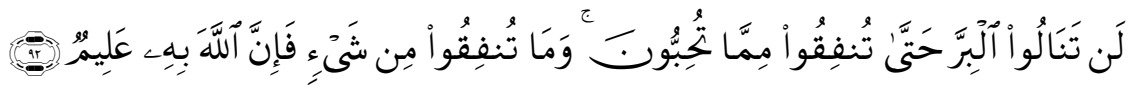

You never get to virtue (perfect); before you spend part that which you love. And whatever you spend verily Allah knows.

The contribution of donated land certification in Islamic view was stated by a informant, Ach. Badrus Salam:14 The reason of donating land or buildings was because of charity of me and my family. The lands or buildings were registered as donation declaration certification (AIW) to get reward and to fulfill the parents' wish. The benefit of registering a land or a building as donated land certification was to avoid claims from heirs in the future. The benefits of registering AIW and donated land certification is to share their fellow Muslims wealth. AIW is processed when the activities referred to an initiative of the individual, family and community leaders. Information of donated land certification was obtained from Islamic College of NATA [STAI NATA] Sampang. People worried that their land will be taken back by the owner if it was not certified yet. The wide of the land or building that will be certified is $\pm 20 \times 10 \mathrm{M} 2$. The culture of donations in Madura had developed well throughout the island. The donated land certification can benefits wâqif, nâdzir, and Muslims in general.

On the other hand, Amsadin 15 said that the contribution of donated land certification is very beneficial. The land or building donated for charity was registered as donation declaration certification (AIW) and donated land certification to avoid of being disturbed by heirs' family and claims in the future. The purpose of registering in AIW and donated land certification was to have a legal recognition. There are several factors affecting this matter such as the initiative, personal, family and public figures. The information of

14Interview with Ach Badrus Salam (Darul Ittihad Foundation, Banyumas Village of Sampang Subdistrict, November 23, 2015.

15Interview with Amsadin, Kendal Kampung, Baruh Village of Sampang Subdistrict, November 23, 2015. 
donated land certification is obtained from ministry of religious affair in Sampang. The people worried that there will be some problems in the future if their lands are not certified yet. The wide of building that will be certified is $\pm 500 \mathrm{M}^{\wedge} 2$. As Islam recommends donations and the culture supports the donation, the development of donation in Madura runs smoothly because of profitable endowments and the fairness in economic standpoint.

Furthermore, Badrus Sholeh ${ }^{16}$ said that a land or building was donated for the purpose of the development and advancement of education. It was registered as donation declaration certification (AIW) and donated land certification to show the status of the land that is used for the worship. The requirement of registering AIW and donated land certificationis to submit a project proposal of madrasah development. There are several factors contributing to this process. One of them is the initiative and the appeal of community leaders. The information of donated land certification was obtained from Ministry of Religious Affairs in Sampang. If the land is not certified yet, there will be a probability that the land will be retaken by the heirs of land. The land and wide area of building that will be certified is assessed independently. As Islam recommends donation and Madurese culture also supports the donation, the donation will remain as a habit and a culture of Madura. The development of donation in Madura increases significantly especially for the purpose of the development of madrasah (Islamic school).

Another informant, Mohammad Shahid, also said that ${ }^{17}$ the land or building was donated for the purpose of goodness. It was registered as adonation declaration certification (AIW) and a donated land certification to avoid claims. This legal certification will make the existence of theland and buildings are stronger. There are several factors influencing this process. One of them is the community initiatives. The information of donated land certification was obtained from Ministry of Religious Affairs in Sampang. People think that if the land endowmentis not registered and certified yet, the status will

\footnotetext{
16Interview with Badrus Sholeh (MD Nurul Hidayah, Gunung Maddah Village of Sampang Subdistrict, November 24, 2015.

17Interview with Moh Syahid (Ar-Rohman Foundation, Jl. Keramat 99 Sampang), November 25, 2015.
} 
be very weak and may remain problematic in the future. The wide of the land or building that will be certified is about $\pm 200 \mathrm{M}^{\wedge} 2$. Islam recommends donation although this is not supported yet by a culture of Madura. The development of donation in Madura develops significantly especially in accordance with the development project of madrasah (Islamic school). Society in general benefits from donation as it supports the economy in terms of productive donation.

Besides, another respondent, H. Zainuddin, said that ${ }^{18}$ the land or building was donated for the sake of perpetual charity. It was registered as a donation declaration certification (AIW) and a donated land certification to avoid claims from family and to have a legal status for the purpose of education. The donated land certification information was obtained from KUA Sampang. If the donated land is not registered and certified yet, the status will be very weak and may face some problems in future. The wide of the land or building that will be certified is $\pm 10 \times 15 \mathrm{M}^{\wedge} 2$. As Islam recommends donation, this practice is still as a habit of Madurese because it is not a culture of Madura. The development of donation in Madura increases significantly especially related to development projects of madrasah. Wâqif and nâdzir are profitable in donation as well as they support the economy because the donation is productive.

Another informant is Hosnan. He said that ${ }^{19}$ the land or building was donated for perpetual charity. They were, then, registered as a donation declaration certification (AIW) and a donated land certification to avoid claims from family and for legality of the status of land. The information of a donated land certification was obtained from Ministry of Religious Affairs, Sampang. If the donated land is not certified yet, people feel worried that the land will be retaken by the heirs in the future. The wide of the land or building that will be certified is $\pm 500 \mathrm{M}^{\wedge} 2$. Although Islam recommends donation, this practice is still as a habit of Madurese because it is not a culture of Madura. The development of donations in Madura increases significantly especially related to development projects of

\footnotetext{
18Interview with H. Zainuddin (An-Najabah Foundation, Jl. Rajawali No. 1 Sampang), November 22, 2015.

${ }^{19}$ Interview with Hosnan (Musholla Foundation, Kendal Kampung, Baruh Village of Sampang Subdistrict, November 25, 2015.
} 
Madrasah. Wâqif and nâdzir are profitable in donations as they support the economy in terms of productive donation.

The further research participant is Syafi'ih. He explained that ${ }^{20}$ the lands or buildings were donated for the purpose of a sustainable development. They were registered as donation declaration certification (AIW) and as donated land certification to achieve the safety and convenience the lands or building being donated. The benefit of the registration of AIW and donated land certification is for the success of worship. This becomes community initiatives and demands. The information of donated land was obtained from Ministry of Religious Affair in Sampang. If the donated land is not certified yet, there will be a probability of misusing the land or building in the future. The wide of the land or building that will be certified still remains partial. Although Islam recommends donation, this practice is still as a habit of Madurese because it is not a culture of Madura. The development of donation in Madura plays a significant role especially if it is related with the development projects of Islamic institution or school (madrasah). The community gets profits from land donation and this supports their economy because the donation is classified as a productive donation.

In addition, Ismail stated that ${ }^{21}$ land or building was donated for an education charity. It was registered as donation declaration certification (AIW) and as donated land certification in order to have a legal certificate. Such this process is taken to avoid a claim from family members who have already donated their land by questioning the legality of land. The benefit of registering the land or building on AIW and on donated land certification is to avoid of misusing of donation for the purpose of the community leader. The information of donated land certification was obtained from the Ministry of Religious Affair in Sampang. If the land is not certified yet, they feel worried that their land will be retaken by their heirs in the future. The wide of the land or building that will be certified remains partial. Although, Islam recommends donation, this practice is still as a habit

${ }^{20}$ Interview with Imam Syafi'ih (Foundation of Nurul Iman Mosque, Gunung Maddah Village of Sampang Subdistrict, November 22, 2015.

${ }^{21}$ Interview with Ismail (Foundation of Miftahul Ulum Islamic Education, Barat Kampung of Mandangin Island, Sampang Regency, November 26, 2015. 
of Madurese because it is not a culture of Madura. The development of donation in Madura develops significantly especially if it is related with the development projects of Madrasah. Indeed, wâqif and nâdzir get profits from land donation and this supports their economy because the donation is classified as a productive donation.

Furthermore, M. Fauzi said that 22 the land or building was donated for the purpose of education charity and getting a reward from Allah. It was registered as donation declaration certification (AIW) and as donated land certification to differentiate the legality between a private land and donated land and to avoid a claim from the familyof donated land questioning its legality. The benefit of registering the land as AIW and as donated land certification is to avoid doubts and anticipate problems in the future. The information of donated land certification was obtained from the Ministry of Religious Affair in Sampang. If the donated land is not certified yet, it may be retaken by heirs and there is probability of a quarrel to occur in in the future. The wide of land or building that will be certified remains partial. Although, Islam recommends donation, this practice is still as a habit of Madurese because it is not a culture of Madura. The development of donation in Madura increases significantly especially if it is related to the development project of madrasah. In fact, wâqif and nâdzir get profits from land donation and this supports their economy because the donation is classified as a productive donation.

In different situation, Moh Ghufron said that ${ }^{23}$ the land or building was donated for social charity. It was registered as donation declaration certification (AIW) and as donated land certification a dispute in the future. The benefit of registering the donated land as donation declaration certification (AIW) and as donated land certification is to provide the legality of the land being donated. The information of donated land certification was obtained from the Ministry of Religious Affair in Sampang. Such this process is taken to anticipate the claim of the land legality in the future if it is not

22Interview with M. Fauzi (Foundation of TPQ Darul Ulum, Barisan Indah, Sampang Subdistrict, November 28, 2015.

${ }^{23}$ Interview with Moh Ghufron (Tanwirul Ulum Islam III Foundation, Tanggumung Village of Sampang Subdistrict, November 27, 2015. 
certified yet. The wide of the land or building that will be certified is approximately $\pm 560 \mathrm{M}^{\wedge} 2$. Although Islam recommends donation, this practice is still as a habit of Madurese because it is not a culture of Madura. The development of donation in Madura increases significantly especially related to the development project of madrasah. Then, wâqif and nâdzir get profits from land donation and this supports their economy because the donation is classified as a productive donation.

Moreover, Mohammad Halimi said that ${ }^{24}$ the lands or buildings were donated for education purposes. They were registered as donation declaration certification (AIW) and as donated land certification to get the legality status of the land status of the land being donated and to avoid the claims in the future. The information of the donated land certification was obtained from the Ministry of Religious Affair in Sampang. This process is applied to avoid the probability of retaking the land by the heirs in the future if it is certified yet. The wide land or building that will be certified is about \pm $560 \mathrm{M}^{\wedge} 2$. Although, Islam recommends donation, this practice is still as a habit of Madurese because it is not a culture of Madura. The development of donation in Madura develops significantly especially related to the development project of madrasah. Wâqif and nâdzir get profits from land donation and this supports their economy because the donation is classified as a productive donation.

Another research participant is Siti Aminah. She argued that ${ }^{25}$ the lands or buildings were donated for the education purpose. They were registered as donation declaration certification (AIW) and as donated land certification to get the legality status of the land being donated and to avoid a dispute to occur in the future. The information of donated land certification was obtained from the Ministry of Religious Affair in Sampang. If the donated land is not certified yet, there will a probability of of retaking by heirs in the future. The wide land or building that will be certified is approximately $\pm 1,000$ hectares. Although Islam recommends donation, this practice is still

${ }^{24}$ Interview with Mohammad Halimi (Foundation of TPQ Raudlatul Muta'allimin, Jl. H. Agus Salim Gg. VI Sampang), November 28, 2015.

25Interview with Siti Aminah (Foundation of SDI Nurul Jadid Jl. Rong Tengah Wangean Sampang 
as a habit of Madurese because it is not a culture of Madura. The development of donation in Madura develops significantly especially related to the development project of madrasah. Society gets profits from land donation and this supports their economy because the donation is classified as a productive donation.

Siti Rodiyah, one of research participants in this research project, argued that ${ }^{26}$ the land or building was donated for here after investment. It was registered as donation declaration certification (AIW) and as donated land certification for the purpose of legal status in order to avoid claims to occur in the future. The information of donated land certification was obtained from the Ministry of Religious Affair in Sampang. If the donated land is not certified yet, there will be a probability that the land will be retaken by the heirs in the future. The wide land or building that will be certified still remains partial. Although Islam recommends donation, this practice is still as a habit of Madurese because it is not a culture of Madura. The development of donation in Madura develops significantly especially related to the development projects of madrasah. People gets profits from land donation and this supports their economy because the donation is classified as a productive donation.

Moreover, Shohibul Anwar argued that 27 the land or building was donated for the here after investment. It was registered as donation declaration certification (AIW) and as donated land certification to obtain the official status of the land being donated in order to avoid a claim coming the heirs in the future. The information of donated land certification was obtained from the Ministry of Religious Affair of in Sampang. If the donated land is not certified yet, there will be a probability of retaking the donated land by the heirs in the future. The wide land or building that will be certified still remains partial. Although Islam recommends donation, this practice is still as a habit of Madurese because it is not a culture of Madura. The development donation in Madura increases significantly especially related to the development projects of madrasah. The society

\footnotetext{
${ }^{26}$ Interview with Siti Rodiyah (Foundation of SD Ma'arif, Bantan Selatan Kampung, Taman Sareh Village of Sampang Subdistrict, 29 November, 2015.

27Interview with Shohibul Anwar (Al-Karomah Foundation, Karang Dalam Village of Sampang Subdistrict, 29 November, 2015.
} 
gets profits from land donation and this supportstheir economy because the donation is classified as a productive donation.

Furthermore, I analyze several statements of informants mentioned above and concludes that the land or building donation is conducted for the purpose of the investment of here after. Another objective is to harmonize the needs of the world matter and here after. The world matter refers to the shared culture and generosity, while the need of here after refers to people comprehension that there must be a better life that lasts very long after the people died. In addition, the donation declaration certification (AIW) and the donated land certification is applied to get the legal status of the land and to avoid disputes in the future. The benefit of having the donated land certificate is to anticipate of being retaken by the heirs and quarrels because of the land in the future. This indicates that the community begins to realize and obey the law about the importance of the official and legal status of the land. The ownership the donated land must have an official and legal document both de facto and de Jure.

The phenomenon of the donated land certification in subdistrict Sampang, as stated by Ach. Badrus Salam, ${ }^{28}$ indicates the absence of the dispute and quarrel among wâqif family or heirs upon the submission of the donated land to nâdzir when the wâqif died. Although the nâdzir does not process the donated land certification in PPAIW and BPN, the response or feedback of PPAIW is highly needed. This is due to the fact that it is not accustomed in Sampang. It takes 2 months to manage the donated land certification in PPAIW and KUA Sampang and the administration cost IDR. 2,000,000. There is no different service between the donated land and non-donated land in BPN. The duration of managing land and the cost should be paid remain the same as in PPAIW and KUA.

Moreover, as Amsadin said, ${ }^{29}$ although the status of the land or building is still owned as a private property, quarrels and disputes among family or heirs upon the submission of the donated land by wâqif and nâdzir. The donated land certification is not processed both

${ }^{28}$ Interview with Ach Badrus Salam (Darul Ittihad Institution, Banyumas Village of Sampang Subdistrict), November 23, 2015.

${ }^{29}$ Interviewwith Amsadin (Baruh Village of Sampang Subdistrict), November 23, 2015. 
in PPAIW and BPN, but PPAIW always responds well. This is because such kind of this process is not accustomed in Sampang. He further mentions that he does not know the amount of time needed in PPAIW or KUA to publish the donated land certificate. Indeed, there is no different service between the donated land and non-donated land certification in BPN. He also does not know how many days will BPN office take to produce the certificate.

Furthermore, Badrus Sholeh said that ${ }^{30}$ the status of land or building is secure owned by as a private property. No quarrels among family or heirs are found to occur upon the submission of donated land by wâqif and nâdzir even when the wâqif died. He further argues that the donated land is registered yet to PPAIW and BPN to get a legal certificate as it is very difficult. He does not know the detail process of organizing the donated land certificate, in terms of time and administration fee needed in PPAIW or KUA subdistrict Sampang. There is no different service between donated land and non-donated land certification in BPN. This also applies to process the donated land certificate in BPN.

One of the research participant, Mohammad Syahid, explained ${ }^{31} t$ here are two statuses of the land, private land and donated land. On one hand, aquarrel among family or heirs upon submission of the donated land by wâqif and nâdzir occurs when wâqif died in. On the other hand, no heirs request the land being donated to be returned, although the wâqif died. He further states that he has managed his land to get certificate both in PPAIW and BPN. The response or feedback of PPAIW is very beneficial. Some argue that they have not managed a certificate of the donated land yet because of their reluctance to process it. It takes two weeks to process the certification of the donated land in PPAIW or KUA. There is no different service between the donated land and non-donated land certification in BPN.

\footnotetext{
${ }^{30}$ Interview with Badrus Sholeh (MD Nurul Hidayah, Gunung Maddah Village of Sampang Subdistrict), November 24, 2015.

31Interview with Moh Syahid (Ar-Rohman Foundation, Jl. Keramat 99 Sampang), November 24, 2015.
} 
Furthermore, H. Zainuddin explained that ${ }^{32}$ the status of land and building there is free from quarrel upon the submission of the donated land by wâqif and nâdzir with absence of the approval from candidate of heirs of wâqif. Although the wâqif died, none of heirs who requested the land to be returned. The nâdzir does not manage to get a land certificate from PPAIW and BPN because it is not accustomed in Sampang. The time duration of managing a certificate for a donated land in PPAIW and KUA is around 2 months and the administration fee applies, IDR. 2,000,000. There is no different service between the donated land and non-donated land certification process in BPN. The length of time and administration fee needed to manage a land certificate in BPN remains the same as in KUA.

Another research informant in this research is Hosnan. He explained that ${ }^{33}$ the tatus of the land and building is still owned as a private property. There is no quarrel to happen among the family or heirs upon submission of the donated land by wâqif to nâdzir although without the approval from candidate of heirs of wâqif. When the wâqif died, none of the heirs who requested the land being donated to be returned back. He, then, argues that the does not manage to have a land certificate from PPAIW and BPN because it is not accustomed in Sampang. He does not know details concerning the length of time and administration fee applied in managing the donated land certificate in PPAIW or KUA. There is no different service between the donated land and non-donated land certification process in BPN.

As a research participant in this research, Imam Shafi'ih also explained that ${ }^{34}$ the status of the land and building is still owned as a private property. No quarrel seems to occur among family or heirs upon submission of the donated land by wâqif to nâdzir although without an approval from candidate of heirs of wâqif even when the wâqif died. He never manages to get the land certificate to PPAIW and BPN. He does not know exactly the details information about the length of time and administration fee applied in managing a

32Interview with H. Zainuddin (An-Najabah Foundation, Jl. Rajawali No. 1 Sampang), November 25, 2015.

33Interview Hosnan (Musholla Foundation, Baruh Village of Sampang Subdistrict), November 26, 2015.

${ }^{34}$ Interview with Imam Syafi'ih (Foundation of Nurul Iman Mosque, Gunung Maddah Village of Sampang Subdistrict, November 22, 2015. 
certificate of donated land in PPAIW or KUA. As he knows there is no different service between the donated land and non-donated land certification process in BPN.

Ismail, then, also explained that ${ }^{35}$ that the status of the land or building is still owned as a private property. No quarrel seems to happen among the family or heirs upon the submission of the donated land by wâaif to nâdzir although without an approval from candidate of heirs of wâqif even when the wâqif died. He also does not manage to get a land certificate from PPAIW and BPN because it is not accustomed in Sampang. He further states that he does not know the detail length of time and administration fee applied in managing a certificate of the donated land in PPAIW or KUA. As he has known that there is no different service between the donated land and nondonated land certification process in BPN.

M. Fauzi as one of persons who gets involved in this research argued that ${ }^{36}$ that the status of the land or building is still owned as a private property. No quarrel seems to occur among the family or heirs upon submission of the donated land by wâqif to nâdzir although without an approval from heirs of wâqif even when the wâqif died requesting to return back the land being donated. He, then, explains that he manages a certificate of the donated land in PPAIW and BPN. Previously, this is quite rare to find people manage a certificate for the donated land because it is not accustomed in Sampang. He does not know the detail information about the length of time and administration fee applied to manage the donated land certificate in PPAIW or KUA Sampang. There is a different service between the donated land and non-donated land in BPN. The length of time applied in BPN is around 3 months and administration applied is approximately IDR. 3,000,000.

Another research participant, Moh Ghufron, also explained that ${ }^{37}$ the status of the land or building is still owned as a private property. No quarrel seems to happen among family or heirs upon

35Interview with Ismail (Foundation of Miftahul Ulum Islamic Education, Barat Kampung of Mandangin Island, Sampang Regency, November 26, 2015.

${ }^{36}$ Interview with M. Fauzi (Foundation of TPQ Darul Ulum, Barisan Indah, Sampang Subdistrict, November 28, 2015.

37Interview with M. Ghufron (Foundation of Tanwirul Ulum Islam III, Barisan Indah, Sampang Subdistrict) November 24, 2015. 
submission of the donated land by wâqif to nâdzir although without an approval from the candidate of heirs of wâqif even when wâqif died by taking back the land being donated. He further argues that he never manages a certificate of the donated land in PPAIW and BPN as it is not accustomed in Sampang. He does not know the detail information of the length of time and administration fee applied in managing a certificate of the donated land in PPAIW/ KUA. There is no different service between the donated land and non-donated land certification process in BPN.

Moh Tahsin is one of the research participant who says that ${ }^{38}$ the the status of the land or building is still owned as a private property. No quarrel seems to happen among family or heirs upon the submission of donated land by wâqif to nâdzir although without the approval from candidate of heirs of wâqif even when the wâqif died by asking the land to be returned back. He told that he manage a certificate for the donated land in PPAIW and BPN. Previously, none of us who manages a certificate for the donated land because we do not know the procedure. The length of time needed to process in PPAIW or KUA sub district is about one week. There is no different service between the donated land and non-donated land certification process in BPN. The time duration needed in BPN to process a land certificate is 1 week and the administration fee applied is depended on the wide of the land.

Furthermore, Mohammad Halimi explained that ${ }^{39}$ that the status of the donated land or building is clear and no quarrel seems to happen among the family or heirs upon the submission of donated land by wâqif to nâdzir although without the approval from heirs of wâqif. When the wâqif died, none of the heirs who request the land to be returned back. He also states that he does not process a land certificate in PPAIW and BPN because it is not accustomed in Sampang. He further tells that he does not know the detail information about the duration of time needed and administration fee applied in processing a certificate of the donated land in PPAIW or

${ }^{38}$ Interview with Moh Tahsin (Nurul Huda Foundation, Sampang), November 29, 2015.

${ }^{39}$ Interview with Mohammad Halimi (Foundation of TPQ Raudlatul Muta'allimin, Jl. H. Agus Salim Gg. VI Sampang), November 28, 2015. 
KUA. There is no different service between the donated land and nondonated land certification process in BPN. He also argues that he does not know the detail information about the length time and administration fee applied in BPN.

The next research participant is Siti Amina. She explained that 40 that the donated land or building did not lead to quarrel among the family or heirs upon the submission of donated land by wâqif to nâdzir although without the approval from the candidate of heirs of wâqif. When wâqif died, none of the heirs who requested the land to be returned back. She further explains that she never processed to get certificate of the donated land or building in PPAIW and BPN because it is not accustomed in Sampang. This is due to the fact that she does not know the detail information about the duration of time and administration fee to process a certificate of the donated land both in PPAIW or KUA and BPN. There is no different service between the donated land and non-donated land certification process in BPN.

Another research participant, Sohibul Anwar ${ }^{41}$ and Siti Rodiyah ${ }^{42}$ explained thatalmost no quarrel seems to happen among the family or heirs upon the submission of the donated land by wâqif to nâdzir although without the approval from the candidate of heirs of wâqif. When wâqif died, none of the heirs who requested the land to be returned back. He, then, states that he never processesthe donated lands or buildings to get a certificate in PPAIW and BPN because it is not accustomed in Sampang. The duration of time in processing a certificate of the donated land in PPAIW or KUA Sampang is approximately week. There is no different service between the donated land and non-donated land certification process in BPN and no clear information of the length of time and administration fee applied in BPN.

Based on the writer's analysis towards the statements of informants above, it can be concluded that the phenomenon upon the submission of the donated lands by wâqif to nâdzir is without the

\footnotetext{
40Interview with Siti Aminah (Foundation of SDI Nurul Jadid Jl. Rong Tengah Wangean Sampang

${ }^{41}$ Interview with Shohibul Anwar (Al-Karomah Foundation, Karang Dalam Village of Sampang, November 25, 2015.

42Interview with Siti Rodiyah (Foundation of SD Ma'arif, Bantan Selatan Kampung, Taman Sareh Village of Sampang Subdistrict, 29 November, 2015.
} 
approval from the candidate of heirs of wâqif. This indicates that when wâqif died, there is a probability of quarrel to happen in the future by requeting the land to be returned back to the heirs. Another phenomenon that becomes a problem is that the society still do not have comprehensive understanding and are not familiar with the procedures and mechanism to manage the donated land certification. From this point of view, it is necessary to socialize the procedures of the donated land certification to the grassroots so that people will have a holistic comprehension. The role and function of PPAIW and BPN become a medium for understanding the donated land certification. In addition, there are different versions in the community about the the donated land certification service, in terms of administration and the amount of money should be spent on. It is necessary to socialize and advertise standard operational procedure (SOP) and cost of the donated land certification process applied in BPN.Subdistrict),

The alternative solution of the donated land certification in the sub district of Sampang, as stated by Ach Badrus Salam, 43 is that there will be a mediation if aquarrel has already happened by the community leaders and owner of the land being donated. The challenge that inhibits the donated land certification process is the availability of the money. The submission of the donated land is not enough to be conducted orally, it is suggested to make an official agreement or memorandum of understanding $(\mathrm{MoU})$. The donated land certification process will take approximately 1 year. People can seriously initiate and manage a certificate of the donated land by visiting PPAIW. To encourage wâqif to manage the donated land certification is by giving holistic information about the procedure. The strategy that can be applied is that when the process last very long in PPAIW and BPN, the wâqif to nâdzir has to actively approach the officers.

Furthermore, Amsadin explained that ${ }^{44}$ there was a mediation when the quarrel had happened and the mediation was led by

${ }^{43}$ Interview with Badrus Sholeh (MD Nurul Hidayah, Gunung Maddah Village of Sampang Subdistrict, November 24, 2015.

44Interview with Amsadin, Kendal Kampung, Baruh Village of Sampang Subdistrict, November 23, 2015. 
community leaders and the land owner. The challenge, then, that inhibits the donated land certification process is the amount of money that should be spent on it. The submission of the donated land is not enough to be conducted orally, it is suggested to make an official agreement or memorandum of understanding (MoU). The length of time needed to publish a certificate for the donated land is one month. The strong evidence is people's seriousness to manage a donated land certificate is by participating a workshop about it and then register the donated land to get a certificate in PPAIW. One of the strategy to encourage nâdzir to manage the donated land certification is by explaining to nâdzir the importance of having a certificate for a donated land. When the process of managing a certificate of donated land lasts very long in PPAIW and BPN, nâdzir has to seriously and actively approach some officers in PPAIW and BPN.

Then, Badrus Sholeh as the participant in this research project explained that 45 there was a mediation when a quarrel had happened and it was led by the chief of village. The challenge that inhibits the donated land certification process is the amount of money that should be spent on it. The submission of the donated property is not enough to be conducted orally, it is suggested to make an official agreement or memorandum of understanding (MoU). The length of time needed to publish a certificate for the donated land is one month. One of the strategy to encourage nâdzir to manage the donated land certification is by explaining to nâdzir the importance of having a certificate for a donated land. When the process of managing a certificate of donated land lasts very long in PPAIW and BPN, nâdzir has to seriously report to PPAIW and BPN.

In addtion, Mohammad Syahid explained that ${ }^{46}$ there was mediation when a quarrel had occurred and it was led by community leaders and polices in Sampang. The challenge that inhibits the donated land certification process is the amount of money that should be spent on it. The submission of the donated property is not enough to be conducted orally, it is suggested to make an official agreement

${ }^{45}$ Interview with Badrus Sholeh (MD Nurul Hidayah, Gunung Maddah Village of Sampang Subdistrict, November 24, 2015.

46Interview with Moh Syahid (Ar-Rohman Foundation, Jl. Keramat 99 Sampang), November 25, 2015. 
or memorandum of understanding $(\mathrm{MoU})$. The length of time needed to publish a certificate for the donated land is one month. One of the strategy to encourage nâdzir of Regional Board of Nahdatul Ulama Sampang to manage the donated land certification is by explaining to nâdzir the importance of having a certificate for a donated land. When the process of managing a certificate of the donated land lasts very long in PPAIW and BPN, nâdzir has to intensively communicate with the officers in PPAIW and BPN.

The next research participant is Zainuddin ${ }^{47}$ and Hosnan ${ }^{48}$ stated that there was mediation when a quarrel had happenedand it was handled by community leaders and the owner of the land. The challenge, then, that inhibits the donated land certification process is the amount of money that should be spent on it. The submission of the donated land is not enough to be conducted orally, it is suggested to make an official agreement or memorandum of understanding (MoU). The length of time needed to publish a certificate for the donated land is one month. The strong evidence is people's seriousness to manage a donated land certificate is by participating a workshop about it and then register the donated land to get a certificate in PPAIW. One of the strategy to encourage nâdzir to manage the donated land certification is by explaining to nâdzir the importance of having a certificate for a donated land. When the process of managing a certificate of donated land lasts very long in PPAIW and BPN, nâdzir has to actively approach some officers in PPAIW and BPN.

Another research subject who gets involved in this research project is Imam Syafi'ih. He explained that ${ }^{49}$ there was mediation when a quarrel had happened and it was facilitated by the community leader and the land owner. The challenge that inhibits the donated land certification process is the amount of money that should be spent on it. The submission of the donated land is not enough to be conducted orally, it is suggested to make an official agreement or

47Interview with H. Zainuddin (An-Najabah Foundation, Jl. Rajawali No. 1 Sampang), November 22, 2015.

${ }^{48}$ Interview with Hosnan (Musholla Foundation, Kendal Kampung, Baruh Village of Sampang Subdistrict, November 25, 2015.

${ }^{49}$ Interview with Imam Syafi'ih (Foundation of Nurul Iman Mosque, Gunung Maddah Village of Sampang Subdistrict, November 22, 2015. 
memorandum of understanding (MoU). The length of time needed to publish a certificate for the donated land is one month. The strong evidence is people's seriousness to manage a donated land certificate is by participating a workshop about it and then register the donated land to get a certificate in PPAIW.

As the research participant, Ismail explained that ${ }^{50}$ there was mediation when a quarrel had happened and it was led by the community leader and a police of Sampang. The challenge that inhibits the donated land certification process is the amount of money that should be spent on it. The submission of the donated land is not enough to beconducted orally, it is suggested to make an official agreement or memorandum of understanding (MoU). The length of time needed to publish a certificate for the donated land is one month. The strong evidence is people's seriousness to manage a donated land certificate is by participating a workshop about it and then register the donated land to get a certificate in PPAIW. One of the strategy to encourage nâdzir to manage the donated land certification is by explaining to nâdzir the importance of having a certificate for a donated land. When the process of managing a certificate of donated land lasts very long in PPAIW and BPN, nâdzir has to communicate intensively with the officers of PPAIW and BPN.

Another informant in this research is Moh Ghufron, ${ }^{51}$ Moh Tahsin ${ }^{52}$ and M. Fauzi ${ }^{53}$ who explained that there was a mediation when a quarrel had happened and it was led by the community leader and the owner of the land. The challenge that inhibits the donated land certification process is the amount of money that should be spent on it. The submission of the donated land is not enough to beconducted orally, it is suggested to make an official agreement or memorandum of understanding (MoU). The length of time needed to publish a certificate for the donated land is one month. The strong

\footnotetext{
50Interview with Ismail (Foundation of Miftahul Ulum Islamic Education, Barat Kampung of Mandangin Island, Sampang Regency, November 26, 2015.

51Interview with Moh Ghufron (Tanwirul Ulum Islam III Foundation, Tanggumung Village of Sampang Subdistrict, November 27, 2015.

52Interview with Moh Tahsin (Nurul Huda Foundation, Sampang), November 29, 2015.

53Interview with M. Fauzi (Foundation of TPQ Darul Ulum, Barisan Indah, Sampang Subdistrict, November 28, 2015.
} 
evidence is people's seriousness to manage a donated land certificate is by participating a workshop about it and then register the donated land to get a certificate in PPAIW. One of the strategy to encourage nâdzir to manage the donated land certification is by explaining to nâdzir the importance of having a certificate for a donated land. When the process of managing a certificate of donated land lasts very long in PPAIW and BPN, nâdzir has to communicate actively to the officers of PPAIW and BPN.

In addition, Mohammad Halimi, ${ }^{54}$ Siti Rodiyah, ${ }^{55}$ and Shohibul Anwar ${ }^{56}$ also explained that there was a mediation when a quarrel had happened and it was led by the community leader and the owner of the land. The challenge that inhibits the donated land certification process is the amount of money that should be spent on it. The submission of the donated land is not enough to be conducted orally, it is suggested to make an official agreement or memorandum of understanding (MoU). The length of time needed to publish a certificate for the donated land is one month. The strong evidence is people's seriousness to manage a donated land certificate is by participating a workshop about it and then register the donated land to get a certificate in PPAIW. One of the strategy to encourage nâdzir to manage the donated land certification is by explaining to nâdzir the importance of having a certificate for a donated land. When the process of managing a certificate of donated land lasts very long in PPAIW and BPN, nâdzir has to ask to the officers of PPAIW and BPN what problems that inhibits the establishment of a certificate of the donated land.

Based on the researchfindings, those who have experience of a quarrel with other people, the head of village and the police always play a role as a mediator. Additionally, the submission of the donated property is not sufficient to be conducted orally, it is suggested to make an official agreement or memorandum of understanding $(\mathrm{MoU})$. The most relevant steps that should be taken into account when the

54Interview with Mohammad Halimi (Foundation of TPQ Raudlatul Muta'allimin, Jl. H. Agus Salim Gg. VI Sampang), November 28, 2015.

55Interview with Siti Rodiyah (Foundation of SD Ma'arif, Bantan Selatan Kampung, Taman Sareh Village of Sampang Subdistrict, 29 November, 2015.

56Interview with Shohibul Anwar (Al-Karomah Foundation, Karang Dalam Village of Sampang, November 25, 2015. 
process of getting the certificate of the donated property is to communicate to PPAIW and BPN.

\section{Conclusion}

People donated their property for the purpose of the charity of person their selves and their family. Lands or buildings were registered to get a certificate of the donated land or building to avoid unexpected claims from their heirs. If the property is not register yet, there will be a probability that the heirs will take back the land being donated in the future. The cost for registering the land and building to be certified varies from one to another. The endowments in terms of property [land or building] in Madura do not become a culture although the development of donation in Madura is relatively high.

From the research finding, in general, it can be concluded that a quarrel the donated property has happened but it is very limited and does not affect the process of the certification. None of the heirs who requested the land being donated to be returned when the wâqif died. Most of land or building had been certifiedin PPAIW and BPN. The length of time needed to get a certificate of the donated property in PPAIW or KUA is one week and it is free of charge. There is no different service between the donated land and non-donated in BPN.

When a quarrel occurs, the head of the village and the police officer have a role to play as a mediator. The challenge that inhibits the donated land certification process is the amount of money that should be spent on it. The submission of the donated land is not enough to be conducted orally, it is suggested to make an official agreement or memorandum of understanding (MoU). The length of time needed to publish a certificate for the donated land is one month. When the process of managing a certificate of donated land lasts very long in PPAIW and BPN, some have to initiate to communicate with the officers of PPAIW and BPN.

From the research findings mentioned above, it is suggested and recommended that: the first, the wâqif and nadzir should immediately apply for the donation declaration certification (AIW) in the office of KUA Sampang and BPN Sampang. The second, the officers of KUA Sampang and BPN Sampang should provide the detail information regarding the required documents that should be completed to process a certificated of the donated property (land or 
building) to avoid unexpected claims from the heirs in the future when the wâqif passed away.

\section{Bibliography}

Al-Alabij, H. Adijani. Perwakafan Tanah di Indonesia: Dalam Teori dan Praktek. Jakarta: PT. Raja Grafindo Persada, 2002.

Anshori, Abdul Ghofur. Hukum dan Praktik Perwakafan di Indonesia. Yogyakarta: Pilar Media, 2005.

Arifin, Imron. Penelitian Kualitatif dalam Ilmu-Ilmu Sosial dan Keagamaan. Malang: Kalimasahada Press, 1996.

Arikunto, Suharsimi. Prosedur Penelitian Suatu Pendekatan Praktis. Jakarta: RinekaCipta, 2002.

Direktorat Jenderal Bimbingan Masyarakat Islam. Undang-undang Nomor 41 Tahun 2004 Tentang Wakaf. Jakarta: Departemen Agama, 2011.

Law No. 5 of 1960 about the Basic Regulation of Agrarian

Lubis, Chairuman Pasaribu Suhrawardi K. Hukum Perjanjian dalam Islam. Jakarta: Sinar Grafika, 1996.

Moleong, Lexy J. Metodologi Penelitian Kualitatif. Bandung: PT Remaja RosdaKarya, 2006.

Muhadjir, Noeng. Metodologi Penelitian Kualitatif. Yogyakarta: Reka Serasin, 2000.

Suprayogo, Imam dan Tobroni, Metodologi Penelitian Sosial Agama. Bandung: Remaja Rosdakarya, 2001.

Umar, Nasarudin. Paradigma Baru Wakaf di Indonesia. Jakarta: Direktorat Jendral Bimbingan Masyarakat Islam, 2007.

Wadjdy, Farid dan Mursyid. Wakaf $\mathcal{E}$ Kesejahteraan Ummat. Yogyakarta: Pustaka Pelajar, 2007.

Zulfirman, Wakaf dalam Perundang-undangan di Indonesia. Paper of International Seminar on Waqf as Private Legal Body, Medan 6-7 January, 2003. 